\title{
Poemas irlandeses
}

Marcelo Tápia

\author{
Brendan Kennelly \\ (De A time for voices - selected poems 1960-1990) \\ PROOF
}

I would like all things to be free of me,

Never to murder the days with presupposition,

Never to feel they suffer the imposition

Of having to be this or that. How easy

It is to maim the moment

With expectation, to force it to define

Itself. Beyond all that I am, the sun

Scatters its light as though by accident.

The fox eats its own leg in the trap

To go free. As it limps through the grass

The earth itself appears to bleed.

When the morning light comes up

Who knows what suffering midnight was?

Proof is what I do not need. 
TÁPIA, Marcelo. Poemas irlandeses

PROVA

Queria que tudo fosse livre de mim, Nunca matar os dias com suposições,

Nunca sentir que eles sofrem imposições

De serem isto e não aquilo. É fácil, sim, Mutilar o momento, aleijá-lo

Com expectativas, forçá-lo a definir-se A si mesmo. Além de tudo que sou, o sol Espalha seus raios como se por acaso.

A raposa come o próprio pé na armadilha

Para livrar-se. Enquanto manca pela relva, É a terra que parece sangrar.

Quando chega, então, a luz do dia, Quem sabe da dor que a noite leva?

De prova é que não vou precisar. 


\section{Seamus Heaney}

(De A spirit level)

THE POPLAR

Wind shakes the big poplar, quicksilvering

The whole tree in a single sweep.

What bright scale fell and left this needle quivering?

What loaded balances have come to grief?

\section{O ÁLAMO}

O vento agita o alto álamo, prateando

Toda a árvore numa só varredura.

Que abalo pôs essa agulha tremulando?

Que desequilíbrio trouxe a desventura? 
TÁPIA, Marcelo. Poemas irlandeses

\section{Remembered COlumns}

The solid letters of the world grew airy.

The marble serifs, the clearly blocked uprights

Built upon rocks and set upon the heights

Rose like remembered columns in a story

About the Virgin's house that rose and flew

And landed on the hilltop at Loreto.

I lift my eyes in a light-headed credo,

Discovering what survives translation true.

\section{Colunas eVOcadas}

As letras do mundo tornaram-se etéreas.

Serifas de mármore, sólidas hastes

Erguidas nas rochas e postas nos ápices

Ascenderam como as colunas na história

Da casa da Virgem, que ascendeu ao céu

E pousou no alto da colina em Loreto.

Elevei o olhar num delirante credo

E vi o que subsiste à tradução fiel. 
(De Death of a naturalist)

STORM ON THE ISLAND

We are prepared: we built our houses squat,

Sink walls in rock and roof them with good slate.

This wizened earth has never troubled us

With hay, so, as you see, there are no stacks

Or stooks that can be lost. Nor are there trees

Which might prove company when it blows full

Blast: you know what I mean - leaves and branches

Can raise a tragic chorus in a gale

So that you listen to the thing you fear

Forgetting that it pummels your house too.

But there are no trees, no natural shelter.

You might think that the sea is company,

Exploding comfortably down on the cliffs,

But no: when it begins, the flung spray hits

The very windows, spits like a tame cat

Turned savage. We just sit tight while wind dives

And strafes invisibly. Space is a salvo,

We are bombarded by the empty air.

Strange, it is a huge nothing that we fear. 
TÁPIA, Marcelo. Poemas irlandeses

\section{TEMPESTADE NA ILHA}

Estamos preparados: as casas robustas,

Têm paredes postas na pedra e bem cobertas.

Esta terra seca nunca nos perturbou

Com feno, assim, como pode ver, não há medas

Ou montes que possam perder-se. Nem há árvores

Que nos façam companhia ao soprar violento

$O$ vento: sabe o que digo - folhas e galhos

Entoam um coro trágico no vendaval

De forma que você escute ao que teme e

Esqueça que ele também golpeia a sua casa.

Não há árvores, nem abrigo natural.

Você pensaria que o mar é companheiro,

Explodindo tranqüilo abaixo dos penhascos,

Mas não: quando começa, os borrifos atingem

As janelas, cospem qual gato manso feito

Selvagem. Abraçamo-nos enquanto o vento,

Invisível, atira. $\bigcirc$ espaço é uma rajada,

Somos bombardeados pelo ar vazio.

Estranho, o que tememos é um enorme nada. 


\section{Michael Hartnett}

(De A farewell to English)

\section{5}

I say farewell to English verse,

to those I found in English nets:

my Lorca holding out his arms

to love the beauty of his bullets,

Pasternak who outlived Stalin

and died because of lesser beasts;

to all the poets I have loved

from Wyatt to Robert Browning;

to Father Hopkins in his crowded grave

and to our bugbear Mr Yeats

who forced us into exile

on islands of bad verse.

Among my living friends

there is no poet I do not love

although some write

with bitterness in their hearts;

they are one art, our many arts.

Poets with progress

make no peace or pact.

The act of poetry

is a rebel act. 
TÁPIA, Marcelo. Poemas irlandeses

Eu digo adeus ao verso inglês, que achei, por certo, em rede inglesa: meu Lorca estendendo seus braços a fim de amar a beleza das balas, Pasternak, que sobreviveu a Stálin e morreu devido a menores bestas; a todos os poetas que amei, de Wyatt a Robert Browning; ao Padre Hopkins na tumba sempre cheia de gente, e ao nosso bicho-papão Yeats, que nos impôs o exílio

em ilhas de maus versos.

Entre os meus amigos vivos não há poeta que eu não ame, ainda que alguns escrevam com seus corações tão acres; eles são uma arte, nossas muitas artes.

Poetas que prosseguem não fazem paz nem pacto. O ato da poesia É rebelde de fato. 
This road is not new.

I am not a maker of new things.

I cannot hew

out of the vacuum-cleaner minds

the sense of serving dead kings.

I am nothing new.

I am not a lonely mouth

trying to chew

a niche for culture

in the clergy-cluttered south.

But I will not see

great men go down

who walked in rags

from town to town

finding English a necessary sin, the perfect language to sell pigs in.

I have made my choice

and leave with little weeping.

I have come with meagre voice

to court the language of my people. 
TÁPIA, Marcelo. Poemas irlandeses

Não é nova esta estrada,

nem coisas novas eu forjo.

Não pode ser retirada

das mentes aspirador-de-pó

a idéia de servir a reis mortos.

Não sou novo em nada.

Nem uma boca só eu sou

tentando ver se cava

um nicho para a cultura

no clero-conturbado sul.

Mas não verei, calado,

a queda dos grandes:

os que andam em trapos

pelas cidades, errantes

tendo no inglês um preciso pecado,

língua pra vender porcos no mercado.

Fiz minha escolha e parto

com mínimo choro.

Vim com minha voz parca

cortejar a língua do meu povo. 
(De A necklace of wrens)

THE LAST VISION OF EOghan RUa Ó SÚILlEeABHÁIN

The cow of morning spurted

milk-mist on each glen

and the noise of feet came

from the hills' white sides.

I saw like phantoms

my fellow-workers

and instead of spades and shovels

they had roses on their shoulders.

A última VISÃO de EOghan RuA Ó SúllLEABHÁIN

A vaca da manhã jorrou

névoa-leite em cada vale

e o ruído de pés veio

dos lados alvos das colinas.

Vi como fantasmas

meus companheiros

e em vez das costumeiras pás

tinham rosas em suas espáduas. 


\title{
Michael Longley
}

\author{
Ceasefire
}

I

Put in mind of his own father and moved to tears Achilles took him by hand and pushed the old king Gently away, but Priam curled up at his feet and Wept with him until their sadness filled the building.

II

Taking Hector's corpse into his hands Achilles Made sure it was washed and, for the old king's sake, Laid out in uniform, ready for Priam to carry Wrapped like a present home to Troy at daybreak.

III

When they had eaten together, it pleased them both To stare at each other's beauty as lovers might Achilles built like a god, Priam good-looking still And full of conversation, who earlier had sighed:

IV

'I get down on my knees and to what must be done And kiss Achilles' hand, the killer of my son.' 


\section{Cessar-fogo}

।

Relembrando o próprio pai, lacrimoso, Aquiles

Tomou a mão do velho rei; com gentileza

Afastou-o, mas Príamo abraçou-lhe os pés:

Choraram, e a tenda inundou-se de tristeza.

II

Tendo nas mãos o corpo lavado de Heitor,

Aquiles, que respeito pelo rei nutria,

Embrulhou-o numa túnica, qual presente

A ser ofertado a Tróia ao raiar do dia.

III

Cearam juntos e, então, admiraram a

Beleza um do outro, como o fariam amantes -

Aquiles qual um deus, Príamo ainda belo

E pleno de prosa, ele que suspirara antes:

IV

"Faço o que devo: posto de joelhos me humilho;

Beijo a mão de Aquiles, que aniquilou meu filho."

Nota do trad.: "Ceasefire" - escrito, segundo o autor, quando "se rezava em seu país por um cessar-fogo do Ira" - recria um episódio do canto XXIV da llíada de Homero, no qual o rei Príamo, de Tróia, suplica a Aquiles que lhe entregue o cadáver (ultrajado) de seu filho Heitor. 
TÁPIA, Marcelo. Poemas irlandeses

\section{FROZEN RAIN}

I slow down the waterfall to a chandelier,

Filaments of daylight, bones fleshed out by ice

That recuperate in their bandages of glass

And, where the lake behaves like a spirit level,

I save pockets of air for the otter to breathe.

I magnify each individual blade of grass

With frozen rain, a crop of icicles and twigs,

Fingers and thumbs that beckon towards the thaw

And melt to the marrow between lip and tongue

While the wind strikes the branches like a celeste.

Chuva congelada

Reduzo a cascata a um candelabro, fios

De luz, ossos descarnados pelo gelo

Que se refazem nas bandagens de vidro

$E$, onde o lago age como nível de bolha,

Guardo bolsas de ar para que a lontra viva.

Aumento uma a uma as lâminas de grama

Com brotos, chuva congelada e sincelos,

Polegar, dedos que apontam o degelo

Derretem, entre o lábio e a língua, até o âmago

Enquanto o vento toca órgão nos ramos. 


\section{Derek Mahon}

THE SNOW PARTY

for Louis Asekoff

Basho, coming

To the city of Nagoya,

Is asked to a snow party.

There is a tinkling of china

And tea into china;

There are introductions.

Then everyone

Crowds to the window

To watch the falling snow.

Snow is falling on Nagoya

And farther south

On the tiles of Kyoto.

Eastward, beyond Irago,

It is falling

Like leaves on the cold sea.

Elsewhere they are burning

Witches and heretics

In the boiling squares, 
TÁPIA, Marcelo. Poemas irlandeses

Thousands have died since dawn

In the service

Of barbarous kings;

But there is silence

In the houses of Nagoya

And the hills of Ise. 


\section{A FESTA DA NEVE}

para Louis Asekoff

Bashô, ao chegar a

Nagoya, é chamado

A uma festa da neve.

Há um tinido de xícaras

E chá vertido nas xícaras;

Há apresentações.

Então todos se juntam

Diante da janela

Para ver a neve que cai.

A neve cai em Nagoya

E mais para o sul

Sobre os telhados de Kyoto.

A leste, além de Irago,

Ela cai como folhas

Sobre o mar gelado.

Longe, queimam

Bruxas e hereges

Em praças ferventes, 
TÁPIA, Marcelo. Poemas irlandeses

Milhares morreram

Desde a aurora

A serviço de reis bárbaros;

Mas há silêncio

Nas casas de Nagoya

E nas colinas de Ise. 


\title{
Richard Ryan
}

\author{
AT THE END \\ From the Japanese of Matsuo Basho
}

My spirit and flesh, parting now -

trails of mist here, there,

dwindling in the bone forest.

FIM

Do japonês de Matsuó Bashô

Meus espírito e carne apartam-se agora -

rastros de névoa aqui, acolá,

dissipam-se na floresta de ossos. 
TÁPIA, Marcelo. Poemas irlandeses

\title{
Aidan Carl Mathews
}

THE DEATH OF IRISH

The tide gone out for good,

Thirty-one words for seaweed

Whiten on the foreshore.

A MORTE DO IRLANDÊS

\begin{abstract}
A maré vazia de vez,
Trinta e uma palavras para alga

Empalidecem na praia.
\end{abstract}




\section{Sobre os autores}

Brendan Kennely nasceu em Kerry, em 1936. Publicou, entre outros, os livros Getting up early (1966), Good souls to survive (1967), Bread (1971), Love Cry (1972), The voices (1973), Islandman (1977), The boats are home (1980), Cromwell (1983) e A time for voices: selected poems 1960-1990 (1990).

Seamus Heaney nasceu em 1939, no Condado de Derry, Irlanda do Norte. Publicou, entre outros, os livros de poemas Death of a naturalist (1966), Door into the dark (1969), North (1975), Station Island (1984) e The spirit level (1996), bem como diversos volumes de crítica literária. Ocupou a cadeira de poesia em Oxford por seis anos, e recebeu o Prêmio Nobel de Literatura em 1995. Integrou o "Grupo de Belfast" (também conhecido como "Escola do Norte").

Michael Hartnett / Micheál Ó hArtnéide, nascido em 1941, em Limerick, e morto em 1999, em Dublin, é conhecido por sua atitude contestatória em relação à adoção da língua inglesa pelos poetas irlandeses (durante um período de dez anos, deixou de escrever em inglês, para "produzir apenas na língua do seu povo"). Publicou, entre outros, os livros Anatomy of a cliché (1968), A necklace of wrens (livro bilíngüe, inglês-irlandês) e A farewell do English (1975). Recebeu um prêmio do American Fund Literary; era membro da Aosdána (organização que reúne criadores cujo trabalho tenha especialmente contribuído com a arte irlandesa).

Michael Longley nasceu em Belfast, em 1939. Publicou, entre outros, os livros de poemas No continuing city (1969), Man lying on a wall (1976), Poems 1963-1983 (1984), The ghost orchid (1995) e Broken dishes (1998). É membro da Royal Society of Literature, da Aosdána e do Cultural Traditions Group, que promove a aceitação da diversidade cultural na Irlanda do Norte. Integrou o "Grupo de Belfast".

Derek Mahon, nascido em Belfast em 1941, publicou, entre outros, os livros de poemas Night-crossing (1968), Ecclesiastes (1970), The snow 
party (1975), Poems 1962-78 (1979) e Selected poems (1993). É autor de diversas peças teatrais, como The bacchae: after Euripedes (1991). Editou as antologias Modern Irish poetry (1972) e The Penguin book of contemporary Irish poetry. Recebeu diversos prêmios, entre eles o Irish American Foundation e o Lannan Foundation. Integrou o "Grupo de Belfast", e é membro da Aosdána.

Aidan C. Mathews nasceu em Dublin, em 1956. Publicou, entre outros, os livros de poemas Windfalls (1977) e Minding Ruth (1983), além do volume de narrativas breves Adventures in a Bathyscope (1988).

Richard Ryan nasceu em Dublin, em 1946. Publicou Ledges (1970) e Rave (1973). É embaixador da Irlanda e representante permanente do país nas Nações Unidas.

\section{SOBRE O TRADUTOR}

Marcelo Tápia é poeta, editor e tradutor. Publicou os livros Primitipo (1982), O bagatelista (1985), Rótulo (1990), Livro aberto (1992) e Pedra volátil (1996), além dos volumes de tradução James Joyce - poemas (1985 / 1990), Haikais do tempo / Tankas e haikais da lua (1997) e A foria - alguma poesia irlandesa contemporânea (2004). Graduouse em português e grego na FFLCH-USP.

\section{REFERÊNCIAS BIBLIOGRÁFICAS}

FALLON, Peter e MAHON, Derek (ed.). The Penguin book of contemporary Irish poetry. Londres: Penguin Books, 1990.

MULDOON, Paul (ed.). The Faber book of contemporary Irish poetry. Londres: Faber and Faber, 1986.

HARTNETT, Michael. Collected poems. Dublin: The Gallery Press, 2001. 
HEANEY, Seamus. Death of a naturalist. Londres: Faber and Faber, 1991. The spirit level. Londres: Faber and Faber, 1996.

LONGLEY, Michael. "Two peace poems and a few thoughts about them". In: ABEI Newsletter. São Paulo: Associação Brasileira de Estudos Irlandeses, junho de 1997. 